\title{
SOME PHYSICAL AND MECHANICAL PROPERTIES OF JATROPHA FRUITS
}

\author{
R. A. Werby ${ }^{(1)}$ and A. M. Mousa ${ }^{(2)}$
}

\begin{abstract}
This study was conducted to investigate some physical and mechanical properties of dried Jatropha curcas fruits cultivated in Egypt. The physical and mechanical properties were determined with a moisture content of Jatropha fruit 11.56 (\%, d. b.). The results showed that the mean values of the \%-ages by weight of fruit parts to whole fruit was 66.24, 33.76, 40.85 and 25.39\% for seeds, shells, kernels and husks, respectively. The results also includes the following properties; length, width, thickness, arithmetic and geometric mean diameter, sphericity, aspect ratio, mass and volume of individual fruit, thousand fruit mass, bulk density, surface area and specific surface area, their averages were found to be $26.84 \mathrm{~mm}, 20.73 \mathrm{~mm}, 19.45 \mathrm{~mm}, 22.34 \mathrm{~mm}, 22.10 \mathrm{~mm}, 82.55$ $\%, 77.53 \%, 2.61 \mathrm{~g}, 5.71 \mathrm{~cm}^{3}, 2552.9 \mathrm{~g}, 0.304 \mathrm{~g} / \mathrm{cm}^{3} 1539.1 \mathrm{~mm}^{2}$ and $1.82 \mathrm{~cm}^{2} / \mathrm{cm}^{3}$, respectively. The mean value of angle of repose was 0.523 rad. For the coefficient of static friction; the galvanized iron sheet surface had the lowest value (0.453) followed by aluminum (0.491) while; the rubber surface had the highest value (0.655). For the rupture forces; the force required for rupturing of fruit in the horizontal loading position $(90.56 \mathrm{~N})$ was higher than the force required in the vertical loading position (39.70 N) of the fruit.
\end{abstract}

Keywords: Jatropha fruits, Biodiesel, physical and mechanical properties.

\section{INTRODUCTION}

J atropha is one of the renewable energy plants. Its high potential for production of biodiesel fuel from its seeds; reduces dependence on the fossil diesel and provides the country with energy security, in addition to decrease the environmental pollution from combustion of fossil fuel. Physical and mechanical properties of Jatropha fruits are important in designing the equipment for harvesting, handling, transporting, storage and shelling.

(1): Assoc. Prof. and (2): Lecturer, Agric. Mach. \& Power Eng. Dept., Fac. of Agric. Eng., Al-Azhar Univ., Cairo, Egypt. E-mail: ahmed_mousa123@azhar.edu.eg 
Many authors: Awady and El-Sayed (1994), EL-Raie et al. (1996), Tayle et al. (2011) and Werby et al. (2012) mentioned that the knowledge of the physical and mechanical properties of agricultural products are necessary and important in design of machines and equipment of processing, handling, transporting and storage. Mohsenin (1986) mentioned that the physical properties of agricultural material such as; shape, size, volume, density, porosity and surface area are important and essential engineering data in many problems associated with design of machines or analysis of the behavior of the agricultural products in different processes.

Jatropha "J." is known with different names such as; physic nut, pinonillo, black vomit nut, purging nut (Barbados) and big purge nut, Salawu et al. (2013). The genus of Jatropha is a perennial plant that belongs to the tribe Joannesieae in the Euphorbiaceae family and contains approximately 170 known species, Kumar and Sharma (2008). Jatropha varieties which have been identified include J. curcas, J. integerrima, J. gossypifolia among others. J. curcas has been given the needed attention among the other varieties for its rich source of oil as biofuel (biodiesel), Krishnan and Paramathma, (2009) C. F. Gonu et al. (2015). Pandey et al. (2012) mentioned that the J. curcas is a multipurpose small tree or large shrub and is found throughout the tropical region. J. curcas is a tropical species native to Mexico and Central America, but is widely distributed in wild or semi cultivated stands in Latin America, Africa, India and South-East Asia.

J. curcas is a drought resistant shrub or tree and produces the fruits. Fruits are in the shape of capsules (beans) and usually contain three seeds. These seeds contain various toxic components (phorbol esters, curcin, trypsin inhibitors, lectins and phytates) and are non-edible. The dry seeds are containing the oil with percentage ranging from 32 to $40 \%$ by weight, Cramer (2010).

The aim of this study was to investigate some physical and mechanical properties of the dried J. curcas fruits cultivated in Egypt. The considered parameters were \%-ages of J. curcas fruit parts, axial dimensions, average diameter, shape, mass, volume, bulk density, surface area, specific surface area, angle of repose, coefficient of static fraction and rupture force of fruit. These properties could be used in design and 
PROCESS ENGINEERING

development suitable machines and equipment of handling, transporting storage and shelling of the fruits.

\section{MATERIALS AND METHODS}

\subsection{Sample source and experiments}

The dried Jatropha "J" curcas fruits were obtained from Progress Arboretum (مشتل بروجرس) in Agouza (العجوزة) - Nile Corniche (كورنيش النيل) - Cairo - Egypt. These fruits were cultivated in governorate of Luxor. The fruits were collected from some J. curcas farms after harvesting season of 2015 via nursery owner and stored in plastic bags at ambient temperature. All the experiments were carried out in the Fac. of Agric. Eng., Al-Azhar Univ., Cairo, Egypt.

\subsection{Physical properties of J. curcas fruits}

\subsubsection{Moisture content}

The moisture content of $\mathrm{J}$. curcas fruits was determined by drying method in a hot air oven at $105^{\circ} \mathrm{C}$ for 24 hours. This test was repeated three times. The moisture content " $M_{C}$ " (\%, d. b.) of fruits was determined by using the following equation according to, Kabutey et al. (2015).

$$
M_{C}(\%, d . b)=\frac{m_{b}-m_{a}}{m_{a}} \times 100
$$

where; $\boldsymbol{m}_{\boldsymbol{b}}$ : is the mass of sample before heat treatment, $(\mathrm{g})$.

\subsubsection{Percentages of fruit parts}

$\boldsymbol{m}_{\boldsymbol{a}}$ : is the mass of sample after heat treatment, $(\mathrm{g})$.

50 fruits were randomly selected and masses of individual fruits were determined using a digital electrical balance with accuracy of $0.001 \mathrm{~g}$. The seeds and kernels per fruit were separated manually (Fig. 1) and weighed to determine the percentage of fruit parts (\%, by wt.) from seeds, shells, kernels and husks to whole fruit as shown in the following equations:

$$
\begin{aligned}
& \text { Seeds, }(\%, \text { wt. })=\frac{\text { Mass of seeds }}{\text { Mass of fruit }} \times 100 \\
& \text { Shells, }(\%, \text { wt. })=\frac{\text { Mass of fruit }- \text { Mass of seeds }}{\text { Mass of fruit }} \times 100 \\
& \text { Kernels, }(\%, \mathrm{wt} .)=\frac{\text { Mass of } \text { kernels }}{\text { Mass of fruit }} \times 100 \\
& \text { Husks, }(\%, \mathrm{wt} .)=\frac{\text { Mass of seeds }- \text { Mass of kernels }}{\text { Mass of fruit }} \times 100
\end{aligned}
$$




\subsubsection{Axial dimensions of fruit}

A digital Vernier-caliper with accuracy of $0.01 \mathrm{~mm}$ was used to measure the three axial dimensions of randomly selected 100 fruits. The three axial dimensions of $\mathrm{J}$. curcas fruit are namely length " $\mathrm{L}$, in $\mathrm{mm}$ " (longest intercept), width "W, in mm" (equatorial width perpendicular to L) and thickness " $\mathrm{T}$, in mm" (breadth perpendicular to $\mathrm{L}$ and $\mathrm{W}$ ).

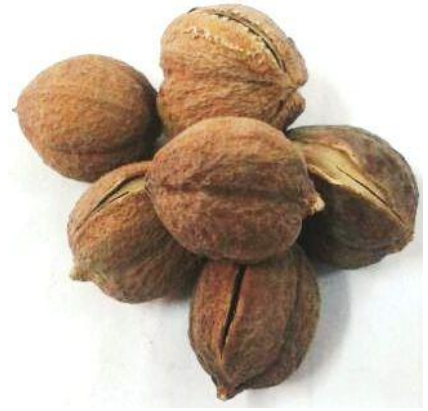

Fruits

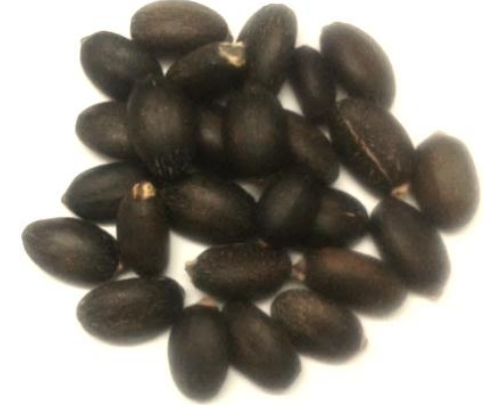

Seeds

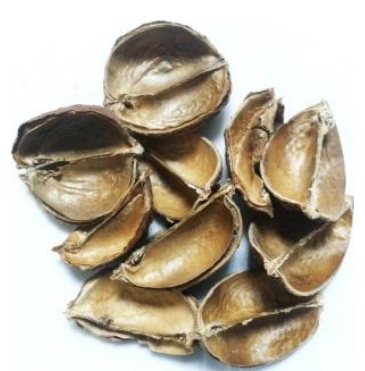

Shells

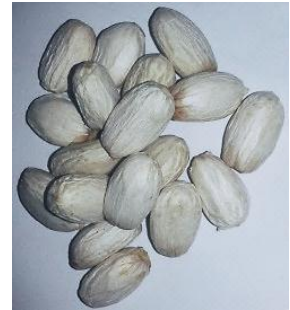

Kernels

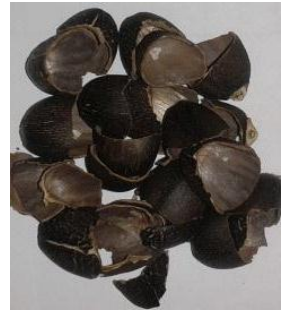

Husks

Fig. (1): J. curcas fruits and their parts.

\subsubsection{Average diameter}

The average diameter of $\mathrm{J}$. curcas fruit was calculated by using the arithmetic mean and geometric mean methods of the three axial dimensions. The arithmetic mean diameter (" $\mathrm{D}_{\mathrm{a}}$ ", in $\mathrm{mm}$ ) and geometric mean diameter (" $\mathrm{Dg}_{\mathrm{g}}$ ", in $\mathrm{mm}$ ) of the $\mathrm{J}$. curcas fruit were calculated by using the following equations according to, Mohsenin (1986).

$$
D_{a}=\frac{L+W+T}{3} \quad \ldots \ldots(6) \quad D_{g}=(L . W . T)^{1 / 3}
$$

\subsubsection{Shape of fruit}

The shapes of seeds and fruits are usually expressed in terms of its sphericity and aspect ratio according to Sahin and Sumnu (2006).

The sphericity (" $\varnothing$ ", \%) of J. curcas fruit was calculated by using the values of the geometric mean diameter and length according to the following equation, Mohsenin (1986). 
PROCESS ENGINEERING

$$
\varnothing=\frac{D_{g}}{L} \times 100
$$

The aspect ratio (" $\mathrm{R}_{\mathrm{a}}$ ", \%) of $\mathrm{J}$. curcas fruit at natural flat position was calculated by using the following equations according to, Maduako and Faborode (1990) C. F. Sahin and Sumnu (2006).

$$
R_{a}=\frac{W}{L} \times 100
$$

\subsubsection{Mass and volume of fruit}

To determine the mass of individual fruit $\left(\mathrm{M}_{\mathrm{f}}\right.$, in $\left.\mathrm{g}\right)$ a 100 it was randomly selected and weighed separately using a digital electrical balance with accuracy of $0.001 \mathrm{~g}$. The volume of individual fruit $\left(\mathrm{V}_{\mathrm{f}}\right.$, in $\mathrm{cm}^{3}$ ) was calculated from values of length ( $\mathrm{L}$, in $\left.\mathrm{mm}\right)$, width $(\mathrm{W}$, in $\mathrm{mm}$ ) and thickness ( $\mathrm{T}$, in $\mathrm{mm}$ ) using the following equation according to, Mohsenin (1986) and Siqueira et al. (2013).

$$
V_{f}=\frac{\pi}{6(1000)}(\text { L.W.T })
$$

\subsubsection{Thousand fruit mass}

150 fruits were randomly selected, then; divided to three groups (50 fruits per test) each group was put in a container and weighed using the digital electrical balance with accuracy of $0.01 \mathrm{~g}$. The mass of 1000 fruit was calculated from the following equation:

1000 fruit mass, $(\mathrm{g})=50$ fruit mass $\times 20 \ldots$

\subsubsection{Bulk density of fruits}

The bulk density (" $\rho_{b}$ " in $\mathrm{g} / \mathrm{cm}^{3}$ ) of $\mathrm{J}$. curcas fruits was determined by putting the fruits into a container of known weight and volume (the volume of container was $3415 \mathrm{~cm}^{3}$ and its height was $14.5 \mathrm{~cm}$ ) and was weighed. This process was repeated five times and the bulk density for each replicate was calculated using the following equation:

$$
\rho_{b}=\frac{m_{f s}}{v_{c}}
$$

where: $m_{f s}:$ is the mass of $\mathrm{J}$. fruits, (g)

$v_{c}$ : is the volume of container used, $\left(\mathrm{cm}^{3}\right)$.

\subsubsection{Surface area and specific surface area}

Surface area is defined as the outside total area of the fruit. The surface area of J. curcas fruit ("S", in $\mathrm{mm}^{2}$ ) was calculated by analogy with a sphere of the same geometric mean diameter using the following equation according to, Siqueira et al. (2013). 


$$
S=\pi D_{g}^{2}
$$

The specific surface area of $J$. curcas fruit ("S $\mathrm{S}_{\mathrm{Sp}}$ " in $\mathrm{cm}^{2} / \mathrm{cm}^{3}$ ) was calculated using the following equation according to, Niveditha et al. (2013).

$$
S_{S p}=\frac{S \times \rho_{b}}{m_{f}}
$$

where: $S$ : is the surface area $\left(\mathrm{cm}^{2}\right)$

$\rho_{b}$ : is the bulk density of fruits, $\left(\mathrm{g} / \mathrm{cm}^{3}\right)$

$m_{f}$ : is the mass of one unit of fruit $(\mathrm{g})$.

\subsection{Mechanical properties}

\subsubsection{Angle of repose}

The angle of repose is the angle between the horizontal surface and inclined side of the formed cone due to free fall of materials. The dynamic angle of repose of $\mathrm{J}$. curcas fruits was measured by emptying method (Karaj and Müller (2010)) to determine the dynamic angle of repose. A hollow PVC cylinder of $105 \mathrm{~mm}$ in diameter and $300 \mathrm{~mm}$ in height and a wooden table were used. The cylinder was placed on the wooden table. Then; it was filled with the J. curcas fruits. The cylinder was raised slowly allowing the fruits to flow down to form a cone of fruits. The diameter and height of the fruits pile were measured and recorded. This experiment was repeated five times and the dynamic angle of repose for each replication was calculated using the following equation:

$$
\theta=\tan ^{-1} \frac{2 H}{D} \times \frac{\pi}{180}
$$

Where; $\theta$ : is the angle of repose, (rad)

$H:$ is the height of the pile, $(\mathrm{cm})$

$D:$ is the diameter of the pile, $(\mathrm{cm})$.

\subsubsection{Coefficient of static fraction}

The coefficient of static fraction of $\mathbf{J}$. curcas fruits was determined on three different materials namely; rubber, aluminum, galvanized iron sheet "G. I. sheet". An open-ended transparent plastic cylinder having $80 \mathrm{~mm}$ internal diameter and $40 \mathrm{~mm}$ height was placed on adjustable tilting plate $(300 \mathrm{~mm} \times 175 \mathrm{~mm})$. The hollow cylinder was filled with 25 fruits, then; the cylinder was raised about $5 \mathrm{~mm}$ so as not to touch the surface. Manually; inclination of the plate was increased gradually until the filled cylinder just started to slide down, this process is according to, Yahya et 
al. (2013). This experiment was repeated ten times and the coefficient of static fraction for each replicate was calculated. The tangent of the slope angle was calculated using the following equation:

$$
\mu=\tan \alpha
$$

Where: $\mu$ : is the coefficient of static fraction and $\alpha$ : is the angle of

\subsubsection{Rupture force} fraction, (degree).

The rupture force is the minimum force required to break the fruit. The rupture force of the $\mathrm{J}$. curcas fruit was determined using a digital force gauge in Agricultural Engineering Research Institute - Agricultural Research Center (Egypt). The specifications of device were as follows: range of the measurement is 0.1 to $500 \mathrm{~N}$ and its accuracy is $0.1 \mathrm{~N}$. 25 fruits were used for vertical loading position "VLP". Also; 25 fruits were used for horizontal loading position "HLP". The individual fruit was put between two parallel plates of the device in either vertical or horizontal loading position. Manually; the compression tool (arm of compression) was used to compress the sample, until the fruit was broken, the loading was stopped and value was recorded.

\subsection{Statistical analysis}

The data obtained were subjected to descriptive statistic such as; range (maximum "Max" and minimum "Min"), mean, standard deviation (SD), coefficient of variation (CV), frequency distribution and coefficient of correlation by using spread sheet software program namely Microsoft Excel (2007).

\subsection{Physical properties}

\section{RESULTS AND DISCUSSIONS}

A summary of the results obtained for physical properties of J. curcas fruits are shown in Table (1).

\subsubsection{Moisture content of dried J. curcas fruits}

Table (1) shows the values of moisture content (\%, d. b.) range, mean, SD and CV, \% for whole fruits. From table (1), the moisture content of J. curcas fruit ranged from 11.36 to $11.66 \%$, d. b., with mean value \pm SD of $11.56 \pm 0.17 \%$, d. b.

\subsubsection{Percentage of $\mathrm{J}$. curcas fruit parts}

Table (1) and Fig. (2) show the values of fruit parts to whole fruit, (\%, wt.). The \%-ages of seeds, shells, kernels and husks ranged from 38.43 to 
$74.08,25.92$ to $61.57,22.96$ to 49.07 and 15.48 to 30.15 (\% wt.) and the mean values were $66.24 \pm 6.12,33.76 \pm 6.12,40.85 \pm 5.65$ and $25.39 \pm$ $2.42 \%$ wt., respectively. Thus; these results may help for determining the mass of seeds in fruits using the following equation: $\mathbf{M}_{\mathbf{s}}=\mathbf{0 . 6 6 2 4} \mathbf{M}_{\mathbf{f}}$ where: $M_{s}$; is the mass of seeds and $M_{f}$; is the mass of fruits.

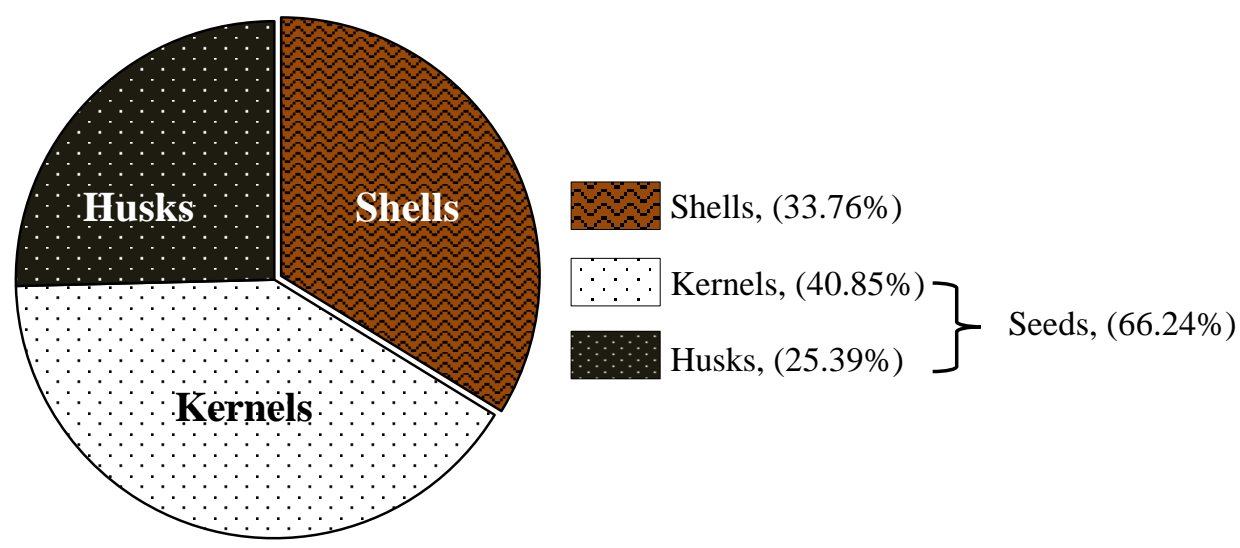

Fig. (2): The percentage of fruit parts, $(\%$, by weight $)$.

Table (1): Physical properties of J. curcas fruits.

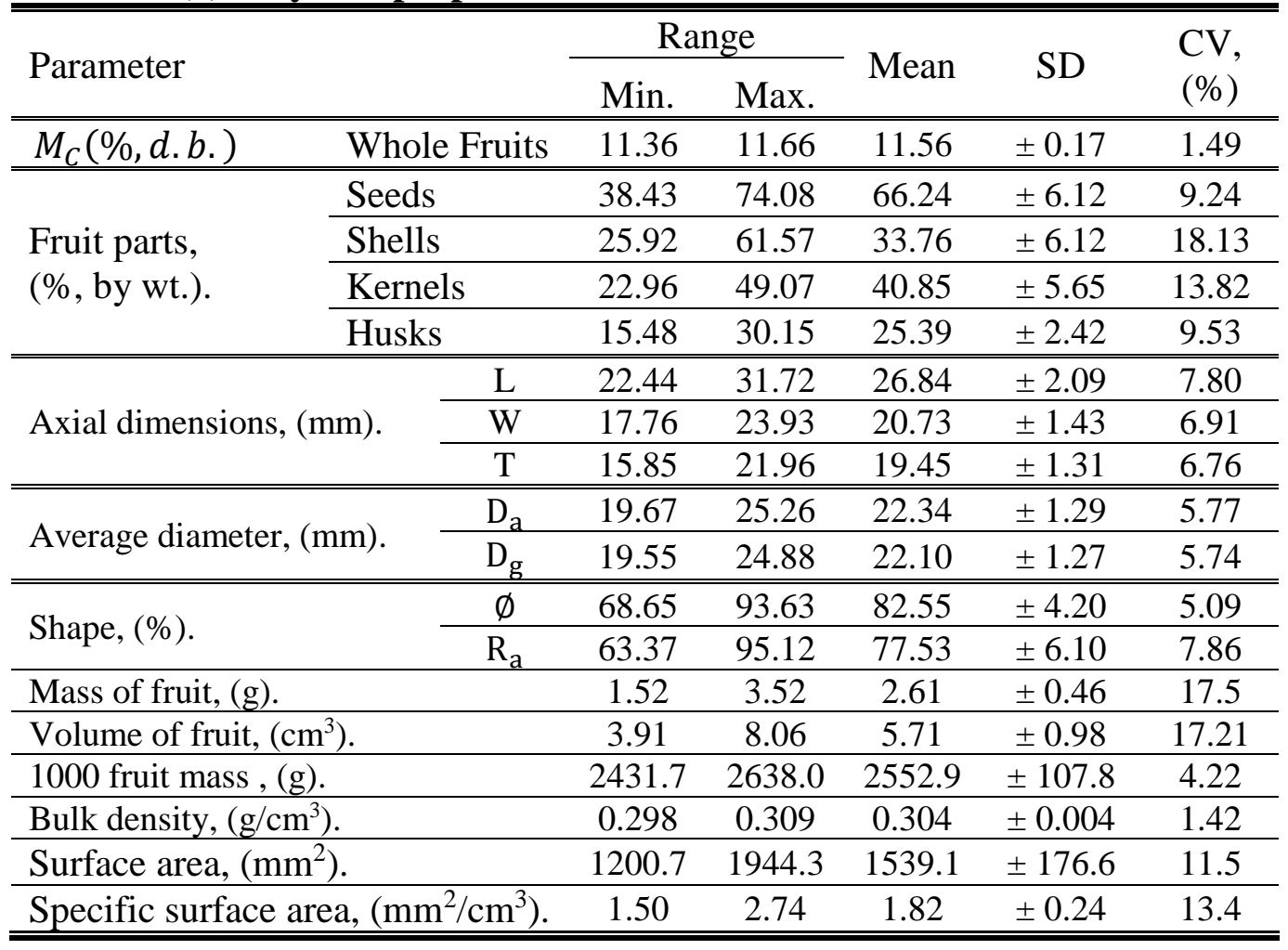




\subsubsection{Axial dimensions of fruit and average diameter}

Three axial dimensions of $\mathbf{J}$. curcas fruits were measured for 100 fruits. From Table (1), the values of length "L" ranged from 22.44 to $31.72 \mathrm{~mm}$ with mean value of $26.84 \pm 2.09$ $\mathrm{mm}$, whereas; the values of width "W" ranged from 17.76 to $23.93 \mathrm{~mm}$ with mean value of $20.73 \pm 1.43$ $\mathrm{mm}$. Also; the values of thickness "T" ranged from 15.85 to $21.96 \mathrm{~mm}$ with mean value of $19.45 \pm 1.31$ mm. Fig. (3) shows the frequency distribution curves of the three axial dimensions of fruits ( $\mathrm{L}, \mathrm{W}$ and $\mathrm{T})$. The highest frequencies of $\mathrm{L}, \mathrm{W}$ and $\mathrm{T}$ were $30 \%$ at $(26.42-27.74 \mathrm{~mm})$, $24 \%$ at $(20.40-21.28 \mathrm{~mm})$ and $30 \%$ at (19.35-20.22 mm), respectively.

The shapes of frequency distribution curves are normal distribution for length, semi-normal distribution for width and left-skewed distribution for thickness.

From Table (1), the values of arithmetic mean diameter $\left(D_{a}\right)$ ranged from 19.67 to $25.26 \mathrm{~mm}$ with mean value of $22.34 \pm 1.29 \mathrm{~mm}$. Meanwhile; the values of the geometric mean diameter " $\mathrm{D}_{\mathrm{g}}$ " ranged from 19.55 to $24.88 \mathrm{~mm}$ with mean value of $22.10 \pm 1.27 \mathrm{~mm}$. Fig. (4) shows the relationship between the arithmetic and geometric mean diameter of $\mathbf{J}$. curcas fruit.
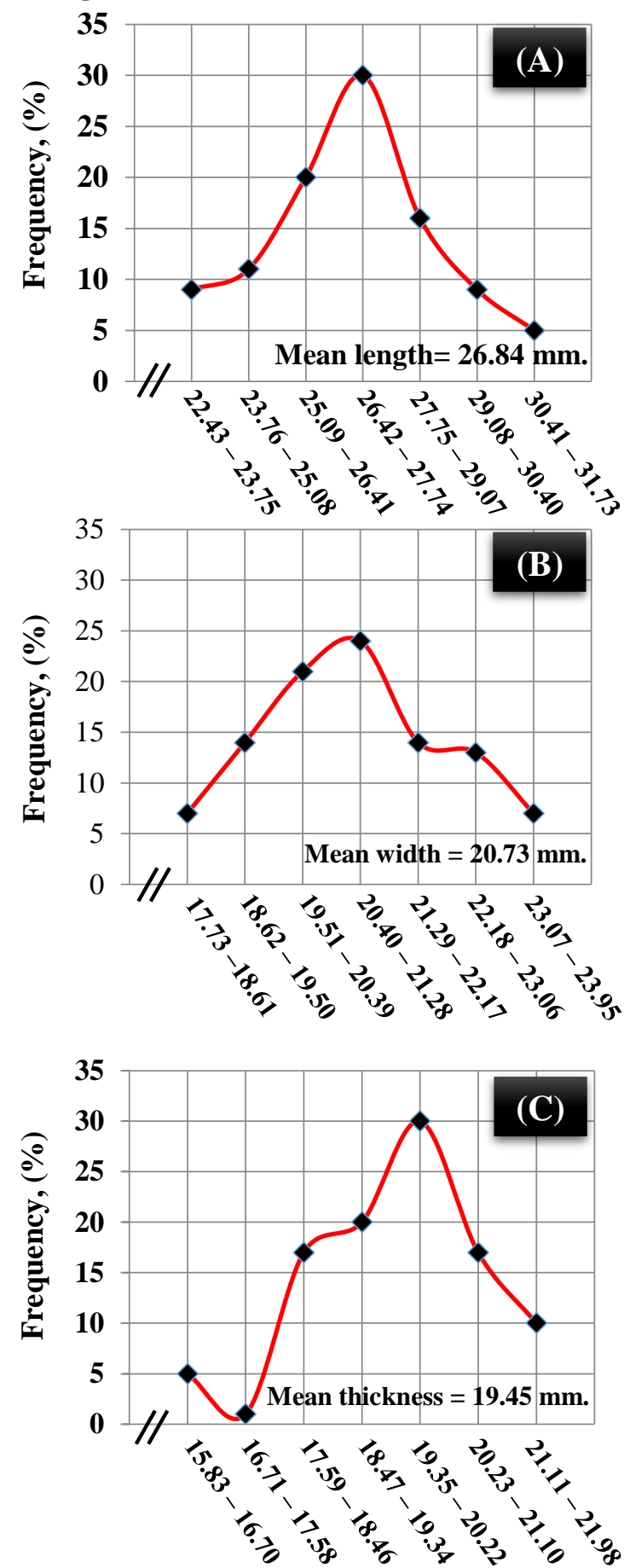

Fig. (3): Frequency distribution curves of the three axial dimensions of $J$. fruit for length (A), width (B) and thickness (C). 
This relationship indicates that the average diameters calculated by the arithmetic and the geometric mean methods were almost same and the coefficient of correlation is very high and closer to 1 " $\mathrm{R}=0.995$ ". So; the correlation between $D_{a}$ and $D_{g}$ is positive strong correlation as shown in Fig. (4). Therefore, either the arithmetic mean or the geometric mean method can be used to calculate the equivalent diameter of J. curcas fruit.

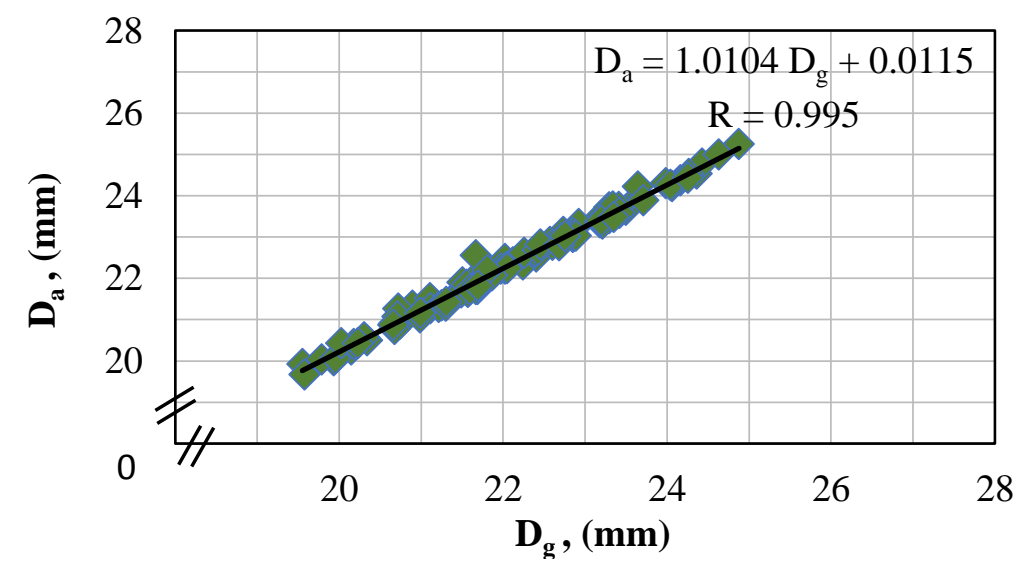

Fig. (4): Arithmetic mean diameter versus geometric mean diameter of $\mathrm{J}$. curcas fruits.

The obtained values of length, width, thickness, arithmetic mean diameter and geometric mean diameter are important to determine the range of clearance or apertures size in the shelling machines of fruit.

\subsubsection{Shape of $\mathbf{J}$. curcas fruit}

The sphericity and aspect ratio were determined to express of the shape of J. curcas fruits. From Table (1), the values of sphericity and aspect ratio ranged from 68.65 to 93.63 and 63.37 to $95.12 \%$ with mean values of $82.55 \pm 4.2$ and $77.53 \pm 6.1 \%$, respectively. This result is an indication that the shape of $\mathrm{J}$. curcas fruit is close to the spherical shape. The corresponding mean values of sphericity and aspect ratio for gbafilo fruit by Davies and Zibokere (2011) were 84 and $75 \%$, respectively and considered very close to the spherical shape, and their results are nearly similar with our results. In addition to Duta et al. (1988) and Bal and Mishra (1988) who considered the grain as spherical where the sphericity value is more than 70 and $80 \%$, respectively. 
These results indicate that the fruits roll rather than slide on the structural surfaces and this property is important in the design of fruit hoppers for handling operations.

\subsubsection{Mass, volume and bulk density}

The results indicate that the values of individual fruit mass ranged from 1.52 to $3.52 \mathrm{~g}$ with mean value of $2.61 \pm 0.46 \mathrm{~g}$. From Table (1), the calculated values of volume ranged from 3.91 to $8.06 \mathrm{~cm}^{3}$ with mean value of $5.71 \pm 0.98 \mathrm{~cm}^{3}$. Also; the results show that the values of the mass of one thousand fruit ranged from 2431.7 to $2638 \mathrm{~g}$ with mean value of $2552.9 \pm 107.8 \mathrm{~g}$. The values of bulk densities ranged from 0.298 to $0.309 \mathrm{~g} / \mathrm{cm}^{3}$ with mean value of $0.304 \pm 0.004 \mathrm{~g} / \mathrm{cm}^{3}$.

The previous properties play an important role for determining the dimensions of storage containers, fruit hopper of handling equipment and transport operations.

\subsubsection{Surface area and specific surface area}

The values of the surface area of fruit ranged from 1200.7 to $1944.3 \mathrm{~mm}^{2}$ with mean value of $1539.1 \pm 176.6 \mathrm{~mm}^{2}$. Meanwhile; the values of the specific surface area ranged from 1.50 to $2.74 \mathrm{~cm}^{2} / \mathrm{cm}^{3}$ with mean value of $1.82 \pm 0.24 \mathrm{~cm}^{2} / \mathrm{cm}^{3}$, as shown in Table (1).

\subsection{Mechanical properties:}

A summary of the results obtained for mechanical properties of J. curcas fruits are shown in Table (2).

Table (2): Mechanical properties of J. curcas fruits.

\begin{tabular}{|c|c|c|c|c|c|c|}
\hline \multirow{2}{*}{\multicolumn{2}{|c|}{ Property }} & \multicolumn{2}{|c|}{ Range } & \multirow{2}{*}{ Mean } & \multirow{2}{*}{ SD } & \multirow{2}{*}{$\begin{array}{l}\mathrm{CV}, \\
(\%)\end{array}$} \\
\hline & & Min. & Max. & & & \\
\hline \multicolumn{2}{|c|}{ Angle of repose, (rad) } & 0.464 & 0.576 & 0.523 & \pm 0.04 & 7.65 \\
\hline \multirow{3}{*}{$\begin{array}{l}\text { Coefficient of } \\
\text { static friction. }\end{array}$} & G. I. sheet & 0.409 & 0.501 & 0.453 & \pm 0.03 & 7.43 \\
\hline & Aluminum & 0.432 & 0.561 & 0.491 & \pm 0.04 & 8.39 \\
\hline & Rubber & 0.559 & 0.838 & 0.655 & \pm 0.08 & 12.60 \\
\hline \multirow{2}{*}{ Rupture force, $(\mathrm{N})$} & H LP & 40.0 & 194.9 & 90.56 & \pm 42.38 & 46.80 \\
\hline & VLP & 19.20 & 71.50 & 39.70 & \pm 14.61 & 36.82 \\
\hline
\end{tabular}




\subsubsection{Angle of repose}

Table (2) shows the values of the dynamic angle of repose on a wooden surface. The angle of repose ranged from 0.464 to 0.576 rad with mean value $0.523 \pm 0.04 \mathrm{rad}$. This result can be used to design the side inclination of fruit hopper of handling machines, silos and storage containers to allow easy sliding.

\subsubsection{Coefficient of static fraction}

The coefficient of static fraction of $J$. curcas fruit against three different structural surfaces (galvanized iron sheet, aluminum and rubber) was determined. From Table (2), the values of coefficient of static fraction ranged from 0.409 to $0.501,0.432$ to 0.561 and 0.559 to 0.838 with mean values of $0.453 \pm 0.03,0.491 \pm 0.04$ and $0.655 \pm 0.08$ for G. I. sheet, aluminum and rubber. The results indicated that the G. I. sheet structural surface had the lowest value of coefficient of static fraction followed by aluminum while; the rubber surface had the highest value of coefficient of static fraction as shown in Fig. (5). Thus it is preferable to use the G. I. sheet as structural surfaces when designing the fruit hopper in handling machines, silos and storage containers.

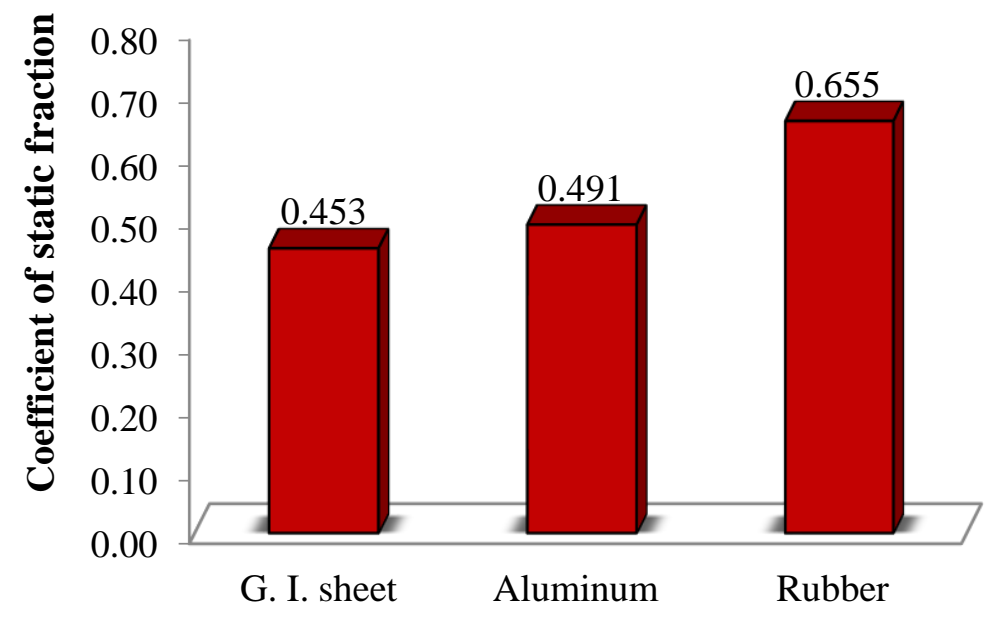

Type of surface

Fig. (5): Average coefficient of static friction of J. curcas fruits on different material surfaces. 


\subsubsection{Rupture force of fruit}

Table (2) shows the values of the rupture force of fruit in the horizontal loading position "HLP" and vertical loading position "VLP". The results showed that the rupture force in the HLP of fruit ranged from 40 to 194.9 $\mathrm{N}$ with mean value of $90.56 \pm 42.38 \mathrm{~N}$. Meanwhile; the rupture force in the VLP of fruit ranged from 19.2 to $71.5 \mathrm{~N}$ with mean value of $39.7 \pm$ $14.61 \mathrm{~N}$. Generally; the results showed that; the force required for rupturing the J. curcas fruit in HLP was higher than the force required in VLP. This result may be attributed to the two areas of contact between the fruit and two compression plates of the device from top and bottom were larger in the horizontal loading position of fruit than in the vertical loading position of fruit.

\section{CONCLUSIONS}

The aim of this study was to investigate some physical and mechanical properties of Jatropha curcas fruit cultivated in Egypt. The obtained results of physical and mechanical properties of Jatropha curcas fruit at moisture content $11.56(\%$, d. b.) can be summarized as follows:

The mean percentage of seeds, shells, kernels and husks per whole fruit were $66.24,33.76,40.85$ and $25.39 \%$ by wt. Length, width, thickness of fruit were 26.84, 20.73 and $19.45 \mathrm{~mm}$. Arithmetic and geometric mean diameter were 22.34 and $22.10 \mathrm{~mm}$. Sphericity and aspect ratio were 82.55 and $77.53 \%$. Mass and volume of individual fruit were $2.61 \mathrm{~g}$ and $5.71 \mathrm{~cm}^{3}$. Mass of one thousand fruit, bulk density, surface area and specific surface area were $2552.9 \mathrm{~g}, 0.304 \mathrm{~g} / \mathrm{cm}^{3}, 1539.1 \mathrm{~mm}^{2}$ and 1.82 $\mathrm{cm}^{2} / \mathrm{cm}^{3}$, respectively.

$>$ The mean value of angle of repose was $0.523 \mathrm{rad}$. For the coefficient of static friction; the galvanized iron sheet surface had the lowest value followed by aluminum while; the rubber surface had the highest value.

The results showed that the mean force required for rupturing of fruit in the horizontal loading position was higher than the force required in the vertical loading position of Jatropha curcas fruit.

$>$ Finally; the results obtained of physical and mechanical properties from this research can be useful for designing of handling equipment, storage and transporting operations, especially; shelling equipment of Jatropha fruits. 


\section{ACKNOWLEDGEMENT}

The authors would like to thank the Agricultural Engineering Research Institute - Agricultural Research Center (Egypt) for his support with a digital force gauge for measuring the rupture force of fruits.

\section{REFERENCES}

Awady M. N. and A. S. El-Sayed (1994). Separation of peanut seeds by air stream, (Egypt) Misr J. Ag. Eng., 11(1): 137-147.

Bal S. and H. N. Mishra (1988). Engineering properties of soybean. Proc. Nat. Sem. Soybean Processing and Utilization in India, Bhopal, Madhya Pradesh, India: 146-165.

Cramer J. (2010). The Jatropha handbook from cultivation to application. (Netherlands): 2. (http://www.slideshare.net/QZ1/w1y47)

Davies R. M. and D. S. Zibokere (2011). Some physical properties of Gbafilo (Chrysobalanus icaco) fruits and kernels preparatory to primary processing. (Nigeria), Int. J. Agric. Res., 6 (12): 848 - 455.

Dutta S. K., V. K. Nema and R. K. Bhardwaj (1988). Physical properties of gram. (India) J. Agric. Eng. Res. 39: 259 - 268.

EL-Raie A., N. A. Hendawy and A. Z. Taib (1996). A study of physical and engineering properties for some agricultural products. Misr J. Ag. Eng. 13 (1): 211 - 236.

Gonu H., N. Opoku, R. Appiah-Opong, K. Joseph, M. T. Barnor and P. Quarm (2015). Phenotypic traits and chemical properties of Jatropha curcas seeds from northern Ghana. European Scientific Journal, 11(9): 327 - 340.

Kabutey A., D. Herák, R. Chotěborský, R. Sigalingging and Č. Mizera (2015). Effect of compression speed on energy requirement and oil yield of Jatropha curcas L. bulk seeds under linear compression, (Czech Republic). Biosys. Eng.; 136: 8 - 13.

Karaj S. and J. Müller (2010). Determination of physical, mechanical and chemical properties of seeds and kernels of Jatropha curcas L. (Germany), Industrial Crops and Products 32: 129 - 138.

Krishnan P. R. and M. Paramathma (2009). Potentials and Jatropha species wealth of India, Current Science 97(7): 1000-1004. (C. F. Gonu et al. (2015)). 
Kumar A. and S. Sharma (2008). An evaluation of multipurpose oil seed crop for industrial uses (Jatropha curcas L.): A review. (India), Industrial Crops and Products, 28 (1): 1 - 10.

Maduako J. N. and M. O. Faborode (1990). Some physical properties of cocoa pods in relation to primary processing. Ife J. Technol., 2: 1 -

7. (C. F. Sahin \& Sumnu (2006)).

Mohsenin N. N. (1986). Physical properties of plant and animal materials. Gordon and Breach Sc. Publ., N.Y.

Niveditha V. R., K. R. Sridhar and D. Balasubramanian (2013). Physical and mechanical properties of seeds and kernels of Canavalia of coastal sand dunes, (India) IFRJ; 20 (4): 1547 - 1554.

Pandey V. C., K. Singh, J. S. Singh, A. Kumar, B. Singh and R. P. Singh (2012). Jatropha curcas: A potential biofuel plant for sustainable environmental development. (India), Renewable and Sustainable Energy Reviews 16: 2870 - 2883

Sahin S. and S. G. Sumnu (2006). Physical properties of foods. USA, Springer, Handbook: 3 - 6.

Salawu A. T., M. L. Suleiman and M. Isiaka (2013). Physical properties of Jatropha curcas seed, (Nigeria) EJPAU “Agr. Eng.”; 16 (4), \# 07.

Siqueira V. C., O. Resende and T. H. Chaves (2013). Shape and size of Jatropha beans (Jatropha curcas L.) during drying at different temperatures. (Brazil) Rev. Ceres Viçosa; 60 (6): 820 - 825.

Tayle S. A., A. A. EL-Nakib, A. K. Zaalouk and A. N. Ahmed (2011). Some physical properties of apricot pits. (Egypt), Misr J. Ag. Eng., 28(1): 149-165.

Werby R. A., A. K. Zaalouk and S. H. Desoky (2012). Physical and mechanical properties of sweet lupine seeds. (Egypt). The $19^{\text {th }}$ Annual Conference of the Misr Soc. of Ag. Eng.: 687-700.

Yahya A., K. Hamdan, T. A. Ishola and H. Suryanto (2013). Physical and mechanical properties of Jatropha curcas L. fruits from different planting densities. (Malaysia), J. Applied sci., 13 (7): 1004-1012. 


\section{الملخص العربى}

\section{بعض الخصائص الطبيعية والميكانيكية لثمار الجاتروفا}

رأفت علي وربي (') و أحمد مصطقى موسى (r)

في الآونة الأخيرة بدأت مصر في زر اعة نبات الجاتروفا الذي يعتبر أحد نباتات الطاقة المتجددة

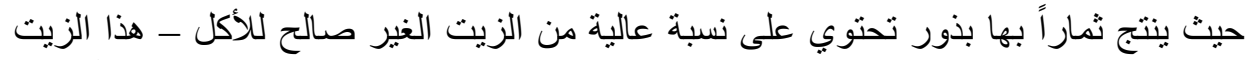

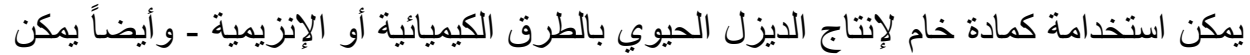

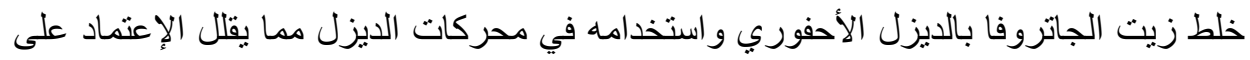

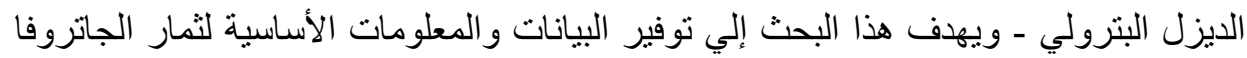

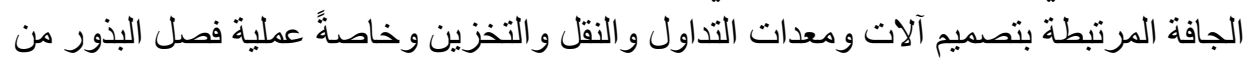
كبسو لات الثمار وذللك من خلال در اسـة بعض الخصائص الطبيعية و الميكانيكية لثمار الجاتروفا الجافة المنزرعة في مصر - وقد تم دراسة خصائص ثمار الجاتروفا عند محتوي رطوبي

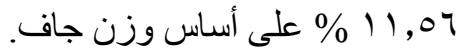

\section{و كانت النتائج المتحصل عليها كالتالى :}

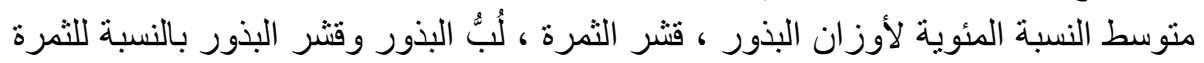

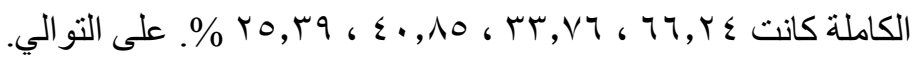

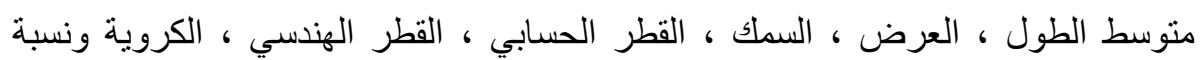

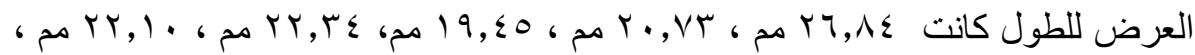

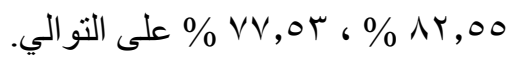

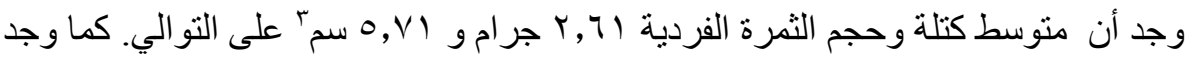

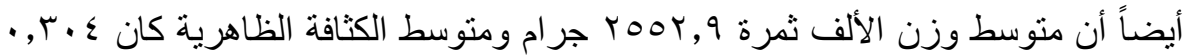

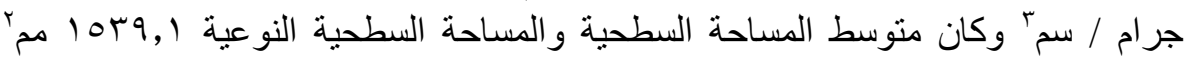

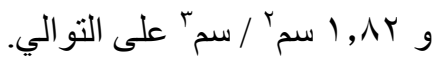

متوسط زاوية المكوث كانت سrه, • زاوية نصف قطرية (rad). كما وجد أيضاً أن أقل

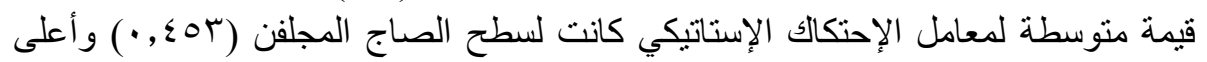

$$
\text { قيمة كانت لسطح المطاط (100 } 700 \text {, •). }
$$

القوة اللازمة لكسر الثمرة في وضع التحميل الأفقي (7ه, • 9 نيوتن) كانت أعلى من القوة

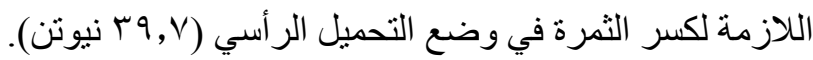

وفي الختام : يمكن الإستفادة من النتائج المتحصل عليها في تصميم معدات التداول والنقل

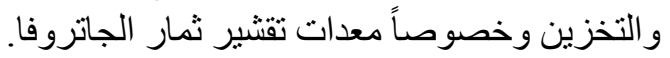

(1): أستاذ مساعد و (Y): مدرس ، قسم هندسة الآلات والقوى الزراعية بكلية الهندسة

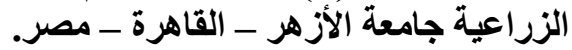

